\title{
ILSE STORCH
}

Condition in chamois populations under different harvest levels in Bavaria 


\section{CONDITION IN CHAMOIS POPULATIONS UNDER DIFFERENT HARVEST LEVELS IN BAVARIA}

ILSE STORCH, Institute of Wildlife Research and Management, University of Munich, Amalienstrasse 52 ,
D-8000 Munich 40, West Germany

Abstract: I studied differences in condition, production, and harvest in 2 neighboring chamois (Rupicapra rupicapra) populations in the Bavarian Alps, Federal Republic of Germany. During 1975-85, chamois shot in Linderhof-Scheinberg (Area 1) were heavier than those from Noth-Kienjoch-Kuchelberg (Area 2). Kidney fat index (KFI) and kid rates were studied in 1985. Kidney fat index and body weight were closely correlated. Throughout the 11-year period, condition and production were highest in Area 1 and yields/unit area were about $30 \%$ greater than in Area 2. Compensatory response to different harvest levels was indicated. The study demonstrated that pronounced differences in dynamics may occur between close subpopulations of mountain ungulates. Managers should be aware that locally distinct management approaches might be required.

J. WILDL. MANAGE. 53(4):925-928

Compensatory response to harvest (Caughley 1985) has been debated for mountain ungulates. Schröder (1985) hypothesized partial reproductive compensation of chamois to hunting. In mountain goats (Oreamnos americanus), reproductive response to harvest was found in introduced (Bailey and Johnson 1977, Swenson 1985, Houston and Stevens 1988) but not in native populations (Hebert and Turnbull 1977, Kuck 1977). Because of these contradictory findings in the North American mountain ungulate, information on the European counterpart would be valuable to understand the population dynamics of chamois and mountain goats. The objective of my study was to demonstrate that important differences in dynamics over time may occur between native subpopulations of chamois and to discuss whether these differences might have resulted from compensatory response to various harvest levels.

I am greatful to the game wardens and foresters of the Forest District of Oberammergau for support, and to P. Alkon, G. R. Iason, W. Schröder, J. E. Swenson, and anonymous referees for valuable comments on earlier drafts of the manuscript.

\section{STUDY AREA AND METHODS}

The $100-\mathrm{km}^{2}$ study area $\left(47^{\circ} 33^{\prime} \mathrm{N}, 11^{\circ} 06^{\prime} \mathrm{E}\right)$ was located in the Ammergauer Mountains in the Bavarian Alps, West Germany. Elevations ranged from $<900$ to peaks $>2,000 \mathrm{~m}$. Climate was moist and temperate. Snowfall varied greatly between years, although the area usually was snow-covered from December through April; snow depth was $\geq 1 \mathrm{~m}$. Slopes were dominated by Norway spruce (Picea abies); patches of dwarf pine (Pinus mugo) and alpine tundra vegetation occurred $>1,500 \mathrm{~m}$.

I subdivided the study area into Area 1 (Linderhof-Scheinberg [30 km²]) and Area 2 (NothKienjoch-Kuchelberg [70 $\left.\mathrm{km}^{2}\right]$ ), which were similar in climate, topography, and vegetation. According to a habitat evaluation for chamois in the Bavarian Alps (Knab 1988), 45 and 46\% of Areas 1 and 2, respectively, were good chamois habitat. Both areas were grazed by livestock to a limited extent. The areas were separated by a valley that functioned as a natural barrier for chamois; however, populations were not completely isolated, and exchange of a few young animals was likely.

Chamois are native and well established in the Bavarian Alps. There were no regular surveys, but game wardens reported that populations have been stable since 1950, except for a few short-term crashes due to severe winters. Wardens believed densities were similar in both areas and estimated a minimum of 6-7 chamois $/ \mathrm{km}^{2}$. Population densities were high compared to other areas of the Alps. The study area was managed by the State Forest Service, and hunting was conducted by game wardens. During the last decades, hunting pressure on chamois has been moderate. Annual yields were $\leq 1$ animal $/ \mathrm{km}^{2}$. Hunters selected chamois according to sex and age classes; sex ratio in the yield was balanced, and within age classes, animals were harvested at random. A few animals that were shot because of disease or visually poor condition were omitted from my analysis. Winter mortality was closely correlated with winter 
Table 1. Body weights $(\mathrm{kg})$ (field dressed without head) of chamois from 2 adjacent areas in the Bavarian Alps, West Germany, 1975-85.

\begin{tabular}{|c|c|c|c|c|c|c|c|c|c|c|}
\hline \multirow[b]{2}{*}{ Sex } & \multirow[b]{2}{*}{ Age class } & \multirow[b]{2}{*}{ Month } & \multicolumn{3}{|c|}{ Area 1} & \multicolumn{3}{|c|}{ Area 2} & \multicolumn{2}{|c|}{$t$-test } \\
\hline & & & $x$ & SD & $N$ & $\bar{x}$ & SD & $N$ & $t$ & $P$ \\
\hline \multirow[t]{7}{*}{ F } & Kid & Sep & 9.0 & 2.8 & 15 & 7.1 & 1.8 & 17 & 2.25 & $<0.05$ \\
\hline & Yearling & Sep-Nov & 12.8 & 2.7 & 9 & 10.1 & 2.3 & 8 & 2.23 & $<0.05$ \\
\hline & $\mathrm{Ad}^{*}$ & Aug & 16.6 & 2.5 & 34 & 15.0 & 1.9 & 77 & 3.34 & $<0.002$ \\
\hline & & Sep & 18.6 & 2.9 & 33 & 15.3 & 2.4 & 31 & 4.97 & $<0.001$ \\
\hline & & Oct & 18.8 & 2.5 & 15 & 15.6 & 2.7 & 39 & 4.08 & $<0.001$ \\
\hline & & Nov & 19.3 & 3.2 & 33 & 15.3 & 2.3 & 54 & 6.35 & $<0.001$ \\
\hline & & Dec & 18.2 & 2.5 & 12 & 15.0 & 1.9 & 39 & 4.09 & $<0.001$ \\
\hline \multirow[t]{7}{*}{ M } & Kid & Sep & 9.8 & 2.1 & 16 & 7.7 & 1.8 & 15 & 2.30 & $<0.01$ \\
\hline & Yearling & Sep-Nov & 12.9 & 2.3 & 11 & 9.9 & 1.5 & 13 & 3.71 & $<0.01$ \\
\hline & $A^{b}$ & Aug & 24.5 & 2.1 & 6 & 21.4 & 3.5 & 35 & 2.98 & $<0.01$ \\
\hline & & Sep & 25.7 & 3.2 & 34 & 22.3 & 3.7 & 27 & 3.78 & $<0.001$ \\
\hline & & Oct & 26.9 & 3.0 & 8 & 23.2 & 4.4 & 12 & 2.24 & $<0.05$ \\
\hline & & Nov & 23.1 & 2.3 & 46 & 22.0 & 2.9 & 59 & 2.17 & $<0.05$ \\
\hline & & Dec & 21.4 & 2.5 & 17 & 20.3 & 2.2 & 14 & 1.30 & $\mathrm{~ns}^{\mathrm{c}}$ \\
\hline
\end{tabular}

$a \geq 5$ yr old.

b $\geq 7$ yr old.

${ }^{c} \mathrm{~ns}=$ not significant

severity (Storch 1986), and during 1975-84, a mean of $13.5 \pm 2.9(\mathrm{SE})$ losses were recorded in Area 1 and $36.9 \pm 9.7$ in Area 2. Predation pressure on chamois was low; all large predators were extirpated in the 1800's. Epidemic diseases were rare.

The local Forest District provided data on 1,121 chamois that were shot in the study area during 1975-85, including date and place of harvest, sex, age (completed yr, determined through horn-segments [Schröder and ElsnerSchack 1985]), and weight (field-dressed without head). Data were analyzed separately for kids, yearlings, and fully-grown adults of each sex. Chamois in the study area reached full body weight at the age of $5(\mathrm{~F})$ and 7 years $(\mathrm{M})$ (Storch 1986); therefore, younger animals were excluded from the adult class for weight analysis. Because no significant between-year variations were found in mean body weights of females or males of either area (Storch 1986) weight data of all years were pooled.

In 1985, game wardens sampled kidneys of 56 chamois. Kidney fat index was calculated according to standard methods (Riney 1955) for chamois $\geq 2$ years (Van Vuren and Coblentz 1985). Production was estimated by observed kid : female ( $\geq 2 \mathrm{yr}$ ) ratios from July and August 1985 during 5 and 3 surveys in Area $\mathrm{l}$ and 2, respectively. Complete counts of chamois are impossible (Schröder 1971). Although females form large groups above timberline during summer, surveys can only comprise samples out of the entire population. Therefore, 1985 summer survey results were pooled to provide a mean kid : female ratio.

\section{RESULTS}

With 1 exception in December, body weights of kids, yearlings, and adults were greater for both sexes in Area 1 than in Area 2 (Table 1). Adult chamois from Area 1 also had greater autumn (Aug-Oct) KFI ( $\mathrm{F}: \bar{x}=81.8$, Area 1 vs. 48.0, Area $2 ; t=2.13,17 \mathrm{df}, P<0.05 ; \mathrm{M}: \bar{x}=$ 175.4, Area 1 vs. 33.0, Area 2 ; $t=6.10,14 \mathrm{df}$, $P<0.001)$. Body weight and KFI were correlated $(r=0.82 ; P<0.001)$ in chamois $\geq 2$ years old (Fig. 1). Females $\geq 2$ years $(n=196)$ with 146 kids were counted in Area 1 (pooled results from 5 surveys) and 120 females with 74 kids were counted in Area 2 (3 surveys) $\left(\chi^{2}=5.79\right.$, $1 \mathrm{df}, P<0.02)$. Kid : female ratios were 0.75 and 0.62 for Area 1 and 2, respectively. From 1975-84, 387 chamois were shot in Area $1(\bar{x}=$ $38.7 \pm 4.0)$ and 678 in Area $2(\bar{x}=67.8 \pm 3.8)$ $\left(\chi^{2}=20.37,1 \mathrm{df}, P<0.001\right)$; i.e., an annual harvest of 1.29 chamois $/ \mathrm{km}^{2}$ in Area 1 and 0.97 chamois $/ \mathrm{km}^{2}$ in Area 2. Because reliable estimates of population size were lacking, harvest rates could not be determined; however, yields/ unit area were consistently greater in Area 1.

\section{DISCUSSION AND MANAGEMENT IMPLICATIONS}

During 1975-85, body weights were greater in chamois shot in Area 1 than in Area 2. When 
analyzed in 1985, fat deposits were greater in chamois in Area 1 than in Area 2. In large mammals KFI values $>80$ indicate good condition, and values $<40$ indicate poor condition (Hanks 1981). Thus, chamois in Area 1 could be considered in good condition, but chamois in Area 2 were in intermediate to poor condition. Kidney fat analysis indicated differences between the populations in 1985. Because KFI and body weight were closely correlated, chamois of Area 1 were probably in better condition during 197585. Kids were heavier in Area 1, which suggested that birth weights were higher and females were in better condition. Molting dynamics provide another index to condition (Geist 1971), and chamois in Area 1 molted earlier (Storch and Schröder 1987).

Throughout the 11-year study period, chamois from Area 1 were in better condition, and the various indicators of condition were positively associated with yield/unit area, which may indicate a compensatory response to different harvest levels. However, although both areas were considered chamois habitats of similar suitability (Knab 1988), actual forage availability remained unknown, and thus the observed differences between chamois in Area 1 and Area 2 also might have been due to inherent differences in habitat quality. These alternative hypotheses could not be discriminated because reliable estimates of chamois density in each area were not available. From 1986, annual yields have doubled in Area 2, and will be kept at this level for several years to reduce chamois density and impact on winter ranges. If chamois condition should improve following the increase in harvest, the compensatory response hypothesis would be supported.

Intensive studies into effects of harvest on chamois are lacking. Bauer (1982) reported density-dependent reproduction in chamois, based on the time chamois had inhabited different areas after introduction in New Zealand. Comparisons of chamois exposed to different harvest regimes in Switzerland showed better condition in the more heavily harvested populations (Hofmann 1978, Brüllhardt 1981). In mountain goats, compensatory reactions to changes in population size were reported in introduced populations (Bailey and Johnson 1977, Swenson 1985, Houston and Stevens 1988), but not in native populations (Hebert and Turnbull 1977, Kuck 1977). The reasons for these conflicting results are unclear. Bailey and Johnson (1977) and

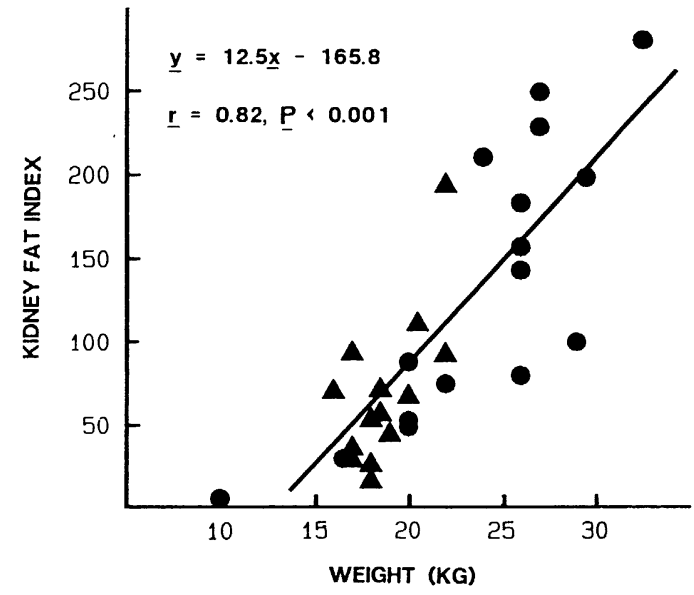

Fig. 1. Correlation between kidney fat index and body weight for female ( $\Delta$ ) and male $(\Theta)$ chamois $\geq 2$ years from 2 adjacent areas in the Bavarian Alps, West Germany, August-December 1985.

Houston and Stevens (1988) speculated that goatinduced changes in vegetation may take a long time to be reversed after density reduction. Resource recovery, and thus a time lag in reproductive response, might depend upon how severely a population had impacted its range. Recently introduced populations might not yet have affected their ranges to the same degree as long-established high-density populations, and response time would be shorter. Hence, reproductive response of established populations might only be found when studied not too shortly after density reduction. Chamois in my study probably were harvested at various levels for $\geq 11$ years, and differences in condition were obvious. Thus, these findings were in accordance with the suggestions described above.

My study demonstrated that pronounced differences in condition over time may occur between close subpopulations of mountain ungulates, and thus, distinct management approaches might be required. If optimization of chamois production for hunting is the management goal, increased harvesting should be recommended where high-density populations appear to be in poor condition. However, managers must be aware that populations may take a long time to respond. Furthermore, computer simulation experiments suggested that chamois were sensitive to overharvest, particularly due to density-independent stochastic effects of winter severity (Schröder et al. 1983, Storch 1986) in alpine habitats. Therefore, only a moderate reduction 
in numbers should be imposed to increase yields in high-density chamois populations exposed to unpredictable environments.

\section{LITERATURE CITED}

BAILEY, J. A., AND B. K. JohNSON. 1977. Status of introduced mountain goats in the Sawatch Range of Colorado. Proc. Int. Mountain Goat Symp. 1: 54-63.

BAUER, J. J. 1982. Untersuchungen zur Dynamik und Kondition von stabilen und kolonisierenden Gemsenpopulationen Neuseelands. Ph.D. Thesis, Univ. Freiburg, FRG. 205pp.

BrüllhardT, H. 1981. Zur jagdlichen Beeinflussung und zur Altersstruktur von Gemspopulationen im Berner Oberland. Ph.D. Thesis, Univ. Bern, Switzerland. 164pp.

Caughley, G. 1985. Harvesting of wildlife: past, present and future. Pages 3-14 in S. L. Beasom and S. F. Roberson, eds. Game harvest management. Caesar Kleberg Wildl. Res. Inst., Kingsville, Tex.

GeIsT, V. 1971. Mountain sheep. A study in behaviour and evolution. Univ. Chicago Press, Ill. 383pp.

HANKS, J. 1981. Characterization of population condition. Pages 47-73 in C. W. Fowler and T. D. Smith, eds. Dynamics of large mammal populations. John Wiley \& Sons, New York, N. Y.

Hebert, D. M., and W. G. Turnbull. 1977. A description of southern interior and coastal mountain goat ecotypes in British Columbia. Proc. Int. Mountain Goat Symp. 1:126-146.

HofmanN, A. 1978. Unterschiedliche Entwicklungsleistungen Appenzeller und Schwyzer Gemsen und ihre möglichen Ursachen. Ph.D. Thesis, Univ. Zürich, Switzerland. 124pp.

Houston, D. B., AND V. STEvens. 1988. Resource limitation in mountain goats: a test by experimental cropping. Can. J. Zool. 66:228-238.
KNAB, C. 1988. Habitatbewertung für Gams in den Bayerischen Alpen. M.S. Thesis, Univ. Munich, FRG. 76pp.

KUCK, L. 1977. The impacts of hunting on Idaho's Pashimeroi Mountain Goat Herd. Proc. Int. Mountain Goat Symp. 1:114-125.

RINEY, T. 1955. Evaluating condition of free-ranging red deer with special reference to New Zealand. New Zealand J. Sci. 36:430-463.

SCHRÖDER, W. 1971. Untersuchungen zur Ökologie des Gamswildes in einem Vorkommen der Alpen. Z. f. Jagdwiss. 17:113-168.

. 1985. Management of mountain ungulates. Pages 179-196 in S. Lovari, ed. The biology and management of mountain ungulates. Croom Helm, London, U.K.

-, AND I. VON ElSNER-SCHACK. 1985. Correct age determination in chamois. Pages $65-70$ in $S$. Lovari, ed. The biology and management of mountain ungulates. Croom Helm, London, U.K.

- - $\longrightarrow$, AND J. SCHRöDER. 1983. Die Gemse. Jahrbuch des Vereins zum Schutz der Bergwelt 48:33-70.

StorCH, I. 1986. Populationsökologie und jagdliche Beeinflussung von Gams in den Ammergauer Alpen. M.S. Thesis, Univ. Munich, FRG. 110pp. , AND W. SCHRÖDER. 1987. Haarwechsel als Konditionsindex für Gamspopulationen. Z. f. Jagdwiss. 33:213-220.

SWENSON, J. E. 1985. Compensatory reproduction in an introduced mountain goat population in the Absaroka Mountains, Montana. J. Wildl. Manage. 49:837-843.

VAN VUREN, D., AND B. E. Coblentz. 1985. Kidney weight variation and the kidney fat index: an evaluation. J. Wildl. Manage. 49:177-179.

Received 18 February 1988.

Accepted 11 April 1989. 